\title{
OPTIMALISASI PEMBUATAN ENZYME MODIFIED CHEESE (EMC) DENGAN KECEPATAN PENGADUKAN DAN SUHU FERMENTASI YANG BERVARIASI
}

\author{
Nana Sutisna Achyadi, Yudi Garnida, Shifa Atiyatul Hasanah \\ Program Studi Teknologi Pangan, Fakultas Teknik, Universitas Pasundan, Jl. Dr.Setiabudi No 93, Bandung, 40153, \\ Indonesia \\ E-mail : nanasutisnaachyadi@unpas.ac.id
}

Diterima pertama kali: 12 Januari 2020, Direvisi: 13 Januari 2020, Disetujui untuk publikasi: 16 Januari 2020

\begin{abstract}
Abstrak
Enzyme Modified Cheese (EMC) is the cheese flavor that was being made through an accelerated enzymatic process by biochemical processes that occur on protein and fat in natural cheese. The research objective is to determine the effect of stirring speed and temperature of fermentation in the manufacture of Enzyme Modified Cheese (EMC) that was made with raw materials Cheddar cheese. The benefits of this research are as diversification to dairy products thereby increasing the economic value and flavor. The study consisted of preliminary and primary research. The preliminary study aims to determine the optimal fermentation time consisting of 6 hours, 8 hours and 10 hours in the manufacturing of Enzyme Modified Cheese (EMC) that taken for the reference for main research. The main research aims to determine the stirring speed and optimal fermentation temperature for the manufacture of Enzyme Modified Cheese (EMC). Stirring speed used was 50 RPM, 60 RPM, and 70 RPM, while the fermentation besides, temperature used was $40^{\circ} \mathrm{C}$, $45^{\circ} \mathrm{C}$, and $50^{\circ} \mathrm{C}$. The experimental design to be used in the research was $(3 \times 3)$ factorial in a randomized block design (RBD) with three replications. Preliminary and primary research responses include chemical response that consists of a water amount, protein amount and fat amount, as well as sensory responses to the aroma and flavor. Based on the results of this study concluded that the sample was selected from the preliminary study is a sample with a fermentation time of 10 hours. Results of a major study presented stirring speed factors affect the water amount, fat amount, aroma and flavor. Fermentation temperature factors affect the water amount, fat amount, aroma and flavor. The interaction between the rate of stirring and the temperature of fermentation affect the water amount, protein amount, aroma and flavor.
\end{abstract}

Keyword : Enzyme Modified Cheese (EMC), stirring speed, temperature fermentation.

\section{Pendahuluan}

Manusia telah mulai mengkomsumsi susu sejak ribuan tahun sebelum masehi. Susu merupakan salah satu produk hasil ternak yang penting bagi kehidupan melalui penyediaan zat gizi yang dibutuhkan oleh semua orang. Namun demikian, susu juga merupakan produk yang mudah rusak, sehingga memerlukan penanganan dan pengolahan secara cepat (Winarno, 1993). Salah satu proses pengolahan susu adalah pembuatan keju secara ekonomis dapat meningkatkan nilai jualnya (Susilorini, 2006). Keju merupakan bahan makanan kaya protein penting bagi kesehatan. Selama ini sebagian masyarakat masih menganggap keju sebagai makanan yang mewah dan mahal. Banyak masyarakat yang belum mengerti cara pembuatan keju sehingga menimbulkan kesan bahwa pembuatan keju sangat sulit (Murti, 2004). Setyawati et al. (2013) adanya perubahan pada produk olahan susu seperti keju disebabkan karena fermentasi laktosa, sitrat, dan senyawa organik lainnya menjadi bermacammacam asam, ester, alkohol dan senyawa pembentuk flavor dan aroma yang mudah menguap. Kebutuhan keju di Indonesia terus meningkat. Berdasarkan data tahun 2002, konsumsi keju nasional sekitar 8000 ton per tahun, meningkat 20\% dibanding tahun 2001. (Rakhman, 2010). Sedangkan tahun 2013, konsumsi keju mencapai sekitar 19.000 ton per tahun. Kebutuhan keju sebagian dipenuhi dengan cara di import, impor keju Indonesia dari Amerika Serikat yaitu sebesar 2.726 ton. Impor keju terus meningkat sebesar 5,96\% per tahun (BPS, 2014). Beberapa dekade terakhir terus meningkat permintaan konsumen terhadap penambahan rasa keju untuk makanan siap saji. Produksi Enzyme Modified Cheese (EMC) merupakan metode yang ekonomis dan konsisten untuk meningkatkan rasa keju dalam produk makanan yang membutuhkan sumber keju Cheedar, Swiss, dll (Mohebbi et. al, 2008). Menurut Patrick F. Fox, et al., (2000), Teknologi yang digunakan untuk memproduksi Enzyme Modified Cheese (EMC) melibatkan inkubasi keju atau curd dengan enzim (protease, peptidase, lipase dan esterase) dalam bentuk adonan pasta dalam kondisi yang terkendali sampai rasa dan aroma yang diinginkan tercapai. Aroma dan rasa Enzyme Modified Cheese (EMC) bisa sampai 30 kali intensitas keju alami. Flavor keju sebagai ingridien untuk mendapatkan aroma dan rasa khas keju dalam pangan olahan, selain dapat menggunakan keju natural atau keju olahan, dapat juga digunakan beberapa bahan sebagai pengganti keju natural. Beberapa jenis produk yang dapat menghasilkan aroma dan rasa khas keju diantaranya keju bubuk, keju modifikasi enzim (Enzyme Modified 
Cheese atau EMC), dan flavor keju lainnya (Missel, 1996).

\section{Metode Penelitian}

Bahan-bahan yang digunakan pada pembuatan Enzyme Modified Cheese (EMC) adalah keju Cheddar, garam pengemulsi, garam rafinasi, air, minyak nabati dan enzim Candida cylindracea.

Bahan-bahan kimia untuk analisis Enzyme Modified Cheese (EMC) adalah aquadest, $\mathrm{NaOH} \mathrm{30 \% ,}$ larutan $\mathrm{H}_{2} \mathrm{SO}_{4}$ pekat, batu didih, granul $\mathrm{Zn}$, larutan $\mathrm{HCl}$

$$
\text { Yijk }=\mu+U+K i+S j+(K S) i j+\varepsilon i j k
$$

$0,01 \mathrm{~N}$, phenolptalein, campuran selen (2 $\mathrm{g}$ serbuk $\mathrm{SeO}_{2}, 100$ gram $\mathrm{K}_{2} \mathrm{SO}_{4}, 20 \mathrm{~g} \mathrm{CuSO}_{4} 5 \mathrm{H}_{2} \mathrm{O}$ ), indikator campuran (bromocresol green $0,1 \%$, metil merah $0,1 \%$, alkohol 95\%), larutan asam borat $\mathrm{H}_{3} \mathrm{BO}_{3}$ dan dietil eter.

Alat-alat yang digunakan pada penelitian Enzyme Modified Cheese (EMC) adalah neraca digital, universal kettle direct steam injection, gelas preaksi, batang pengaduk, termometer, fermetor, cold storage dan wadah tertutup (untuk sampel). Alat untuk analisis penelitian seperti : spatula, cawan petri, neraca analitik, oven, desikator, pipet tetes, pipet volumetri, labu ukur, batang pengaduk, corong, labu Kjeldahl $100 \mathrm{ml}$, alat penyulingan, pemanas listrik atau pembakar, alat ektraksi soxhlet lengkap dengan kondensor dan labu lemak, alat pemanas listrik atau penangas uap, kapas wool, kertas saring.

\section{Penelitian Pendahuluan}

Penelitian pendahuluan dilakukan untuk mengetahui waktu fermentasi yang optimal dalam pembuatan Enzyme Modified Cheese (EMC) dengan kecepatan pengadukan $60 \mathrm{Rpm}$ dan suhu fermentasi $50^{\circ} \mathrm{C}$ dengan waktu yang ditentukan yakni selama 6 jam, 8 jam dan 10 jam. Waktu yang terpilih dipilih dilakukan pengujian secara kimia yang terdiri dari kadar air, kadar protein dan kadar lemak, serta uji organoleptik yang meliputi aroma dan rasa.

\section{Penelitian Utama}

Penelitian utama meupakan penelitian lanjutan dari penelitian pendahuluan yang meliputi: rancangan perlakuan, rancangan statistik, dan rancangan respon.

\section{Rancangan Perlakuan}

Rancangan perlakuan terdiri dari dua faktor yaitu kecepatan pengaukan $(\mathrm{K})$ dan suhu fermentasi ( $\mathrm{T}$ ) yang terdiri dari 3 taraf, yaitu: Kecepatan pengadukan $(\mathrm{K})$ yang meliputi 3 taraf, yaitu:
$\mathrm{K}_{1}=50 \mathrm{Rpm}$

$\mathrm{K}_{2}=60 \mathrm{Rpm}$

$\mathrm{K}_{3}=70 \mathrm{Rpm}$

Suhu fermentasi yang digunakan (S) meliputi 3

taraf, yaitu:

$\mathrm{S}_{1}=40^{\circ} \mathrm{C}$

$\mathrm{S}_{2}=45^{\circ} \mathrm{C}$

$\mathrm{S}_{3}=50^{\circ} \mathrm{C}$

\section{Rancangan Percobaan}

Model rancangan percobaan yang digunakan dalam pembuatan EMC adalah rancangan faktorial $3 \times 3$ dalam rancangan acak kelompok (RAK) dengan 3 kali ulangan, sehingga diperoleh 27 satuan perlakuan.

Model matematika yang digunakan untuk interaksi dalam penelitian adalah sebagai berikut :

Dimana :

$\mathrm{Y}_{\mathrm{ijk}}=$ Nilai respon pada pengamatan ke-i dari faktor kecepatan pengadukan dan taraf ke-j dari faktor suhu fermentasi dan ulangan ke-k.

$\mu=$ Nilai rata-rata respon.

$\mathrm{U}=$ Banyaknya ulangan $(1,2,3)$

$\mathrm{Ki}=$ Pengaruh kecepatan pengadukan ke-i

$\mathrm{Sj}=$ Pengaruh suhu fermentasi pada taraf ke-j.

$\mathrm{KS}_{\mathrm{ij}}=$ Pengaruh dari interaksi antara perlakuan ke-i dari faktor kecepatan pengadukan dengan perlakuan ke-j dari faktor suhu fermentasi.

$\varepsilon_{\mathrm{ijk}}=$ Pengaruh galat percobaan ke-k dari perlakuan kecepatan pengadukan dengan taraf ke-j dari dari perlakuan suhu fermentasi.

\section{Rancang Analisis}

Berdasarkan rancangan percobaan diatas, untuk memudahkan pengujian maka dilakukan uji analisis variasi (ANAVA) dan selanjutnya ditentukan daerah penolakan hipotesis, yaitu:

1. Jika $\mathrm{F}$ hitung $\leq \mathrm{F}$ tabel pada taraf $5 \%$ yang berarti tidak terdapat pengaruh yang nyata atau tidak ada pengaruh kecepatan pengadukan dan suhu fermentasi dalam pembuatan Enzyme Modified Cheese (EMC).

2. Jika $\mathrm{F}$ hitung $>\mathrm{F}$ tabel pada taraf $5 \%$ yang berarti terdapat pengaruh yang nyata atau ada pengaruh kecepatan pengadukan dan suhu fermentasi dalam pembuatan Enzyme Modified Cheese (EMC).

Berdasarkan rancangan diatas dapat dibuat analisis variasi (ANAVA) yang dapat dilihat ditabel berikut ini : 


\begin{tabular}{|c|c|c|c|c|c|}
\hline $\begin{array}{l}\text { Sumber } \\
\text { Variansi }\end{array}$ & $\begin{array}{c}\text { Derajat } \\
\text { Bebas (db) }\end{array}$ & $\begin{array}{c}\text { Jumlah } \\
\text { kuadrat } \\
\text { (JK) }\end{array}$ & $\begin{array}{c}\text { Kuadrat } \\
\text { Tengah } \\
\text { (KT) }\end{array}$ & F Hitung & $\begin{array}{c}\mathrm{F} \\
\text { Tabel }\end{array}$ \\
\hline Kelompok & $\mathrm{r}-1$ & JKK & KTK & & \\
\hline Perlakuan & $k s-1$ & JKP & KTP & & \\
\hline Faktor $\mathrm{K}$ & $k-1$ & $\mathbb{J K}(\mathrm{k})$ & $\mathrm{KT}(\mathrm{k})$ & $\mathrm{KT}(\mathrm{k}) / \mathrm{KTG}$ & \\
\hline Faktor S & $s-1$ & $\mathrm{JK}(\mathrm{s})$ & $\mathrm{KT}(\mathrm{s})$ & $\mathrm{KT}(\mathrm{s}) / \mathrm{KTG}$ & \\
\hline Interaksi KS & $(k-1)(s-1)$ & $\mathrm{JK}(\mathrm{ks})$ & $\mathrm{KT}(\mathrm{ks})$ & $\mathrm{KT}(\mathrm{ks}) / \mathrm{KTG}$ & \\
\hline Galat & $(\mathrm{r}-1)(\mathrm{ks}-1)$ & JKG & KTG & & \\
\hline Total & fks-1 & JKT & & & \\
\hline
\end{tabular}

\section{Rancangan Respon}

Rancangan respon yang digunakan untuk penelitian ini meliputi analisis kimia dan Uji organoleptik.

Analisis kimia : Kadar air metode Gravimetri (AOAC, 2010), kadar protein metode Kjedahl (SNI, 1992) dan kadar lemak metode soxhlet (AOAC, 2010).

\section{Organoleptik}

Tipe pengujian yang dilakukan adalah uji mutu hedonik. Uji mutu hedonik terhadap sampel Enzyme Modified Cheeese (EMC) dilakukan terhadap 5 orang panelis yang berpengalaman dalam bidang keju. Atribut mutu yang dipilih dalam penilaian uji mutu hedonik ini meliputi aroma dan rasa. Contoh kriteria penilaian untuk uji mutu hedonik dapat dilihat pada Tabel 2.

Tabel 2. Kriteria Skala Hedonik

\begin{tabular}{|c|c|}
\hline Kriteria & Nilai \\
\hline Sangat tidak kuat & 1 \\
\hline Tidak kuat & 2 \\
\hline Agak tidak kuat & 3 \\
\hline Agak kuat & 4 \\
\hline Kuat & 5 \\
\hline Sangat kuat & 6 \\
\hline
\end{tabular}

\section{Hasil dan Pembahasan \\ Penelitian Pendahuluan}

Penelitian

pendahuluan dilakukan untuk menetapkan waktu terbaik yang akan digunakan dalam penelitian utama. Penelitian pendahuluan pembuatan Enzyme Modified Cheese (EMC) menggunakan variasi waktu 6 jam, 8 jam dan 10 jam. Waktu fermentasi berpengaruh terhadap aroma dan rasa, dimana waktu fermentasi harus dikendalikan agar produk yang diinginkan didapat, semakin lama waktu fermentasi makan enzim akan terus memecah substrat (lemak dan protein) sehingga hasil berupa aroma dan rasa akan semakin kuat dan bahkan menjadi tidak sesuai yang diinginkan.

Perlakuan penelitian pendahuluan dilakukan pengujian secara inderawi dan kimia (kadar air, kadar protein dan kadar lemak). Uji inderawi

Berdasarkan penelitian pendahuluan pembuatan Enzyme Modified Cheese (EMC) terhadap aroma menunjukkan bahwa sampel terbaik memiliki nilai rata-rata 2,30. Hal ini menunjukan bahwa kecepatan pengadukan dan suhu fermentasi serta interaksinya berpengaruh terhadap aroma dalam pembuatan EMC.

Aroma khas EMC telah muncul pada fermentasi 6 jam, 8 jam dan 10 jam. Namun untuk intensitas aroma yang lebih baik atau kuat berada pada waktu fermentasi $10 \mathrm{jam}$, hal ini dikarenakan proses pemutusan ikatan pada substrat (protein, lemak) yang dipengaruhi oleh kecepatan pengadukan dan suhu fermentasi. Dimana kecepatan pengadukan berfungsi untuk menyebarkan enzim sehingga bekerja secara merata juga dapat meningkatkan suhu fermentasi apabila digunakan kecepatannya tinggi. Suhu fermentasi berpengaruh terhadap kerja enzim. Semakin rendah suhu fermentasi maka kerja enzim semakin melambat, begitupun pada kecepatan pengadukan, semakin rendah kecepatan pengadukan maka kerja enzim lambat. Semakin lama proses fermentasi maka semakin banyak ikatan yang akan teputus sehingga akan mengeluarkan aroma yang keluar lebih kuat, namun apabila tidak dikendalikan maka akan muncul aroma yang tidak diinginkan, aroma yang tidak diinginkan adalah aroma yang dapat menghilangkan aroma khas keju yang dikehendaki.

\section{Rasa}

Berdasarkan hasil penelitian pendahuluan terhadap rasa menunjukkan bahwa Enzyme Modified Cheese (EMC) dengan lama fermentasi 6 jam, 8 jam dan 10 jam telah mengeluarkan rasa khas EMC. Namun rasa pada EMC 10 jam lebih sesuai yang didukung dengan hasil organoleptik dari panelis dengan nilai ratarata 2,39 menunjukan EMC yang dibuat telah stabil dan dapat diaplikasikan ke produk. Kecepatan pengadukan dan suhu fermentasi tidak bepengaruh dalam proses memunculkan aroma, waktu yang berpengaruh dalam proses ini. Semakin lama proses fermentasi maka akan semakin banyak rantai protein yang terpecah sehingga rasa pahit dari amoniak semakin kuat, namun apabila waktu fermentasi terlalu cepat maka rasa khas EMC yang kuat belum muncul sehingga waktu fermentasi perlu dikendalikan agar mendapatkan rasa yang sesuai.

\section{Kadar Air}

Parameter analisis kimia pada Enzyme Modified Cheese (EMC) diantaranya kadar air. Berdasarkan hasil penelitian pendahuluan didapat kadar air pada EMC berkisar antara 52,69\%-54,04\%. Dalam penelitian ini kadar air berpengaruh terhadap tekstur, 
kualitas produk dan umur simpan. Dimana apabila produk memiliki kadar air tinggi akan meningkatkan pertumbuhan bakteri atau jamur yang akan merusak produk, sehingga akan mempengaruhi hasil yang diinginkan, disamping itu akan mengakibatkan tekstur lembek meskipun telah disimpan di ruang pendingin, dan kadar air yang tinggi mengakibatkan produk cepat rusak dikarenakan aktifitas mikroba dengan adanya air semakin meningkat.

Beberapa faktor yang berpengruh dalam proses Pembuatan Enzyme Modified Cheese (EMC) adalah kecepatan pengadukan, suhu fermentasi dan waktu fermentasi. Kecepatan Pengadukan berfungsi untuk meratakan enzim, juga untuk mengoptimalkan kerja enzim. Semakin tinggi kecepatan pegadukan maka akan meningkatkan suhu fermentasi dan meningkatkan uap air. Begitu juga terjadi pada suhu fermentasi. Waktu fermentasi menentukan penurunan komponen substrat dalam produk karena adanya panas, semakin lama proses maka bahan akan terus dipecah oleh enzim dibantu dengan panas sehingga akan mengalami penurunan. Sehingga kedua faktor ini berpengaruh terhadap kadar air dalam pembuatan Enzyme Modified Cheese (EMC).

\section{Kadar Protein}

Berdasarkan hasil penelitian pendahuluan, kadar protein pada Enzyme Modified Cheese (EMC) berkisar antara 8,14\%-8,42\%. Diketahui pada hasil perhitungan uji skoring menunjukkan bahwa semakin lama proses fermentasi makan kandungan protein pada bahan mengalami penurunan meskipun penurunan yang terjadi tidak terlalu besar. Penurunan kadar protein disebabkan terputus ikatan protein yang semakin banyak, salah satunya akan mengeluarkan senyawa volatil atau aroma khas yang kuat.

\section{Kadar Lemak}

Berdasarkan hasil penelitian pendahuluan, kadar lemak pada Enzyme Modified Cheese (EMC) berkisar antara 23,87 \%-24,92\%. Diketahui pada hasil perhitungan uji skoring menunjukkan bahwa semakin lama waktu proses fermentasi maka kandungan lemak pada bahan mengalami penurunan, meskipun penurunan yang terjadi tidak terlalu besar. Penurunan kadar lemak disebabkan semakin banyaknya ikatan yang terputus akibat adanya panas yang keluar disebabkan kecepatan pengadukan yang dapat meningkatkan suhu fermentasi sehingga dapat memunculkan aroma dan rasa yang diinginkan.

\section{Penelitian Utama}

Penelitian utama merupakan lanjutan dari penelitian pendahuluan yang dilakukan untuk mengetahui pengaruh dari variasi kecepatan pengadukan dan suhu fermentasi terhadap aroma dan rasa pada Enzyme Modified Cheese (EMC). Respon penelitian utama produk Enzyme Modified Cheese
(EMC) adalah respon kimia yang meliputi kadar air, kadar protein, dan kadar lemak serta respon inderawi dengan uji mutu hedonik terhadap atribut aroma dan rasa.

\section{Respon Kimia Kadar Air}

Kadar air adalah jumlah air yang terkandung dalam bahan pangan. Penentuan kadar air dalam produk pangan perlu dilakukan karena pengaruhnya terhadap stabilitas dan kualitas dari produk itu sendiri. Masa simpan suatu produk makanan dapat diperpanjang dengan cara menghilangkan sebagian air dari produk pangan tersebut (Buckle, et al, 1986).

Parameter analisis kimia pada Enzyme Modified Cheese (EMC) diantaranya kadar air. Berdasarkan hasil penelitian ini, kadar air pada EMC berkisar antara 53,53\% - 59,81\%. Diketahui pada hasil perhitungan analisis variansi (ANAVA) menunjukkan bahwa perlakuan kecepatan pengadukan, suhu fermentasi, serta interaksinya berpengaruh terhadap kadar air EMC.

Kecepatan pengadukan berfungsi untuk meratakan enzim juga untuk mengoptimalkan kerja enzim. Semakin tinggi kecepatan pegadukan maka akan meningkatkan suhu fermentasi dan meningkatkan uap air. Begitu juga terjadi pada suhu fermentasi, semakin tinggi suhu fermentasi maka uap air yang keluar semakin banyak. Sehingga kedua faktor ini berpengaruh terhadap kadar air dalam pembuatan Enzyme Modified Cheese (EMC).

Berdasarkan uji lanjut duncan perlakuan kecepatan pengadukan pada kecepatan $50 \mathrm{Rpm}$ berbeda dengan kecepatan $60 \mathrm{Rpm}$ dan $70 \mathrm{Rpm}$, hal ini disebabkan pada kecepatan $60 \mathrm{Rpm}$ dan $70 \mathrm{Rpm}$ air bebas yang terkandung dalam bahan telah teruapkan sehigga tersisa air terikat pada bahan, sedangkan pada kecepatan pengadukan $50 \mathrm{Rpm}$ air bebas belum teruapkan sepenuhnya. Hal ini disebabkan semakin tinggi kecepatan pengadukan maka dapat meningkatkan suhu fermentasi. Perlakuan suhu fermentasi didapat suhu 450C berbeda dengan suhu 400C dan 500C dalam proses pembuatan Enzyme Modified Cheese (EMC), hal ini disebabkan dengan adanya panas enzim dapat bekerja dengan optimal pada suhu 500C, namun apabila diatas suhu optimal enzim bekerja menurun, meningkatnya suhu fermentasi sebanding dengan tingginya uap air sehingga kadar air terikat pada bahan bisa lebih banyak

Kadar air erat hubungannya dengan air bebas dan air terikat, dimana air bebas terdapat dibagian permukaan bahan sehingga mudah diuapkan, dari hasil interaksi dapat terlihat pada suhu 400C kandungan air bebas dalam bahan telah teruapkan, sehingga yang tersisa adalah air terikat secara kimia yang berada dalam bahan (berikatan dengan protein, lemak) dalam bentuk kristal

Secara efisiensi pemakaian (manajemen industri), produk yang memiliki kadar air tinggi 
mempunyai banyak kekurangan diantaranya menambah waktu aging, apabila waktu aging ditambah maka stok akan terpendin sehingga akan mempengaruhi proses produksi dan apabila kandungan air terlalu tinggi sudah dapat dipastikan produk tidak bisa digunakan karena berpengaruh terhadap aroma lemah, rasa lemah, tekstur lembek yang tidak dikehendaki sehingga akan mengakibatkan kerugian.

Tabel 3. Pengaruh Interaksi kecepatan pengadukan dan suhu fermentasi Terhadap Kadar Air (\%) Enzyme Modified Cheese (EMC)

\begin{tabular}{|c|c|c|c|}
\hline \multirow{2}{*}{$\begin{array}{l}\text { Kecepatan } \\
\text { Pengadukan }\end{array}$} & \multicolumn{3}{|c|}{ Suhu Fermentasi } \\
\hline & $\mathrm{s} 1\left(40^{\circ} \mathrm{C}\right)$ & $\mathrm{S} 2\left(45^{0} \mathrm{C}\right)$ & $\mathrm{s3}\left(50^{0} \mathrm{C}\right)$ \\
\hline k1 (50 RPM) & ${ }_{\mathrm{b}} 58,41 \quad \mathrm{~B}$ & $\begin{array}{r}\text { A } \\
\mathrm{a}^{53,53}\end{array}$ & $\mathrm{~b}^{57,90}$ \\
\hline k2 (60 RPM) & $\mathrm{b}^{59,81}$ & $\mathrm{a}^{56,76}$ & $\mathrm{~b}^{59,51}$ \\
\hline k3 (70 RPM) & $\begin{array}{ll} & \text { A } \\
\text { ab } & \\
\end{array}$ & $\begin{array}{ll} & \mathrm{C} \\
\mathrm{a} & \\
\end{array}$ & $\mathrm{b}^{59,01}$ \\
\hline
\end{tabular}

Keterangan : Huruf besar dibaca vertikal, huruf kecil dibaca horizontal. Setiap huruf yang sama tidak menunjukkan perbedaan.

Kadar Protein

Berdasarkan hasil penelitian utama, kadar protein pada Enzyme Modified Cheese (EMC) berkisar antara 9,60\% - 10,14\%. Diketahui pada hasil perhitungan analisis variansi (ANAVA) menunjukan adanya interaksi perlakuan kecepatan pengadukan dan suhu fermentasi berpengaruh terhadap proses pembuatan EMC. Kecepatan pengadukan dan suhu fermentasi yang tepat saat digabungkan akan menghasilkan produk yang sesuai, apabila salah satu faktor menggunakan batas minimal maka faktor lain harus menggunakan batas maksimal agar mendapat hasil yang sesuai dan terjadi interaksi antara kedua faktor. Hasil interaksi faktor kecepatan pengadukan dan suhu fermentasi dapat dilihat pada Tabel 4.

Berdasarkan tabel interaksi kadar protein diketahui bahwa dari hasil rata-rata kandungan protein terendah ada pada suhu tertinggi 500C dan kecepatan pengadukan $70 \mathrm{Rpm}$ yaitu 9,60. Kecepatan pengadukan dan suhu fermentasi berpengaruh terhadap proses fermentasi karena dengan kondisi suhu optimal enzim dan kecepatan yang tinggi membuat lebih banyak substrat yang diuraikan sehingga membuat aroma dan rasa semakin kuat. Hal ini muncul dikarenakan protein dipecah dengan adanya 2 faktor di atas menjadi asam amino dan peptida, semakin tinggi kenaikan kecepatan pengadukan dan suhu fermentasi maka asam amino akan disederhanakan kembali kemudian berikatan dengan ester, dan akan memunculkan aroma dan rasa khas protein.
Tabel 4. Pengaruh Interaksi kecepatan pengadukan dan suhu fermentasi Terhadap Kadar Protein (\%) Enzyme Modified Cheese (EMC)

\begin{tabular}{|c|c|c|c|}
\hline \multirow{2}{*}{$\begin{array}{c}\text { Kecepatan } \\
\text { Pengadukan }\end{array}$} & \multicolumn{3}{|c|}{ Suhu Fermentasi } \\
\hline & $\mathrm{s} 1\left(40^{\circ} \mathrm{C}\right)$ & $\mathrm{s} 2\left(45^{0} \mathrm{C}\right)$ & $\mathrm{s} 3\left(50^{\circ} \mathrm{C}\right)$ \\
\hline k1 (50 RPM) & $\mathrm{a}{ }{ }^{\mathrm{A}}$ & $\begin{array}{ll} & \mathrm{AB} \\
\mathrm{a}^{9,74} & \end{array}$ & $\mathrm{a}^{9,97}$ \\
\hline k2 (60 RPM) & $\mathrm{ab}^{9,71}{ }^{\mathrm{A}}$ & $\begin{array}{ll} & \mathrm{A} \\
\mathrm{a} & \\
\end{array}$ & $b^{10,14}$ \\
\hline k3 (70 RPM) & $\mathrm{b}^{10,11^{\mathrm{B}}}$ & $\mathrm{b}^{10,14^{\mathrm{B}}}$ & $a^{9,60}$ \\
\hline
\end{tabular}

Keterangan : Huruf besar dibaca vertikal, huruf kecil dibaca horizontal. Setiap huruf yang sama tidak menunjukan perbedaan. Semakin tinggi kecepatan pengadukan dan suhu fermentasi maka kadar protein semakin menurun.

Kadar Lemak

Berdasarkan hasil penelitian utama, kadar lemak pada Enzyme Modified Cheese (EMC) berkisar antara $20,24 \%$ - 24,93\%. Diketahui pada hasil perhitungan analisis variansi (ANAVA) menunjukkan bahwa perlakuan kecepatan pengadukan dan suhu fermentasi berpengaruh. Berdasarkan tabel anava perlakuan kecepatan pengadukan, suhu fermentasi berpengaruh terhadap kadar lemak Enzyme Modified Cheese (EMC) sehingga dilakukan uji lanjut duncan. Dapat dilihat pada Tabel 5 dan Tabel 6. Berdasarkan tabel kadar lemak diketahui bahwa kecepatan pengadukan 70 Rpm dan suhu fermentasi $500 \mathrm{C}$ berbeda nyata dengan kecepatan pengadukan $50 \mathrm{Rpm}$ dan $60 \mathrm{Rpm}$ dengan suhu fermentasi 400C dan 450C.

Kadar lemak pada suhu 500C dan kecepatan 70 Rpm yaitu 20,24, dimana semakin lama proses fermentasi maka kandungan lemak pada bahan mengalami penurunan, karena adanya perubahan menjadi senyawa lain salah satunya aroma dan rasa, meskipun penurunan yang terjadi tidak terlalu besar.

Tabel 5. Pengaruh Perlakuan Kecepatan Pengadukan Terhadap Kadar Lemak (\%) Enzyme Modified Cheese (EMC)

\begin{tabular}{|c|c|c|}
\hline $\begin{array}{c}\text { Kecepatan } \\
\text { Pengadukan }\end{array}$ & Nilai Rata-Rata & Taraf Nyata \\
\hline k3 (70 Rpm) & 21,94 & $\mathrm{a}$ \\
\hline k1 (50 Rpm) & 23,54 & $\mathrm{~b}$ \\
\hline k2 (60 Rpm) & 24,13 & $\mathrm{~b}$ \\
\hline
\end{tabular}

Keterangan : semakin tinggi kecepatan pengadukan maka kadar lemak produk akan meningkat.

Kecepatan pengadukan akan memudahkan proses pemutusan rantai ikatan pada lemak, semakin tinggi kecepatan pengadukan maka akan meningkatkan suhu fermentasi. Faktor kecepatan dan suhu fermentasi merupakan pendukung terjadinya proses pemutusan 
ikatan rantai pendek yang ada pada bahan yaitu trigliserida dirubah menjadi asam lemak dan gliserol, asam lemak akan berikatan dengan senyawa ester sehingga menghasilkan aroma yang diinginkan. Apabila kedua faktor tidak dikendalikan maka hasil EMC akan menjadi tengik karena terlalu banyak rantai lemak dipecah.

Tabel 6. Pengaruh Perlakuan Suhu Fermentasi Terhadap Kadar Lemak (\%) Enzyme Modified Cheese (EMC)

\begin{tabular}{|c|c|c|}
\hline $\begin{array}{c}\text { Suhu } \\
\text { Fermentasi }\end{array}$ & Nilai Rata-Rata & Taraf Nyata \\
\hline $\mathrm{s} 3\left(50^{\circ} \mathrm{C}\right)$ & 21,75 & $\mathrm{a}$ \\
\hline $\mathrm{s} 1\left(40^{\circ} \mathrm{C}\right)$ & 23,68 & $\mathrm{~b}$ \\
\hline $\mathrm{s} 2\left(45^{\circ} \mathrm{C}\right)$ & 24,18 & $\mathrm{~b}$ \\
\hline
\end{tabular}

Keterangan : semakin tinggi suhu fermentasi maka kadar lemak produk akan meningkat.

\section{Respon Inderawi}

Respon inderawi diperoleh dari hasil pengujian organoleptik. Pengujian organoleptik adalah pengujian yang didasarkan pada proses penginderaan. Pengujian organoleptik yang digunakan adalah uji mutu hedonik dimana yang dinilai oleh panelis adalah kesan terhadap mutu hedonik suatu produk. Kesan mutu hedonik lebih spesifik daripada sekedar kesan suka atau tidak suka. Mutu hedonik dapat bersifat umum yaitu baik buruk dan bersifat spesifik seperti empuk-keras untuk daging, pulen-keras untuk nasi, renyah- lembek untuk mentimun. Rentang skala hedonik berkisar dari ekstrim baik sampai dengan ekstrim buruk atau jelek (Soekarto, 1985).

\section{Aroma}

Aroma merupakan salah satu parameter dalam penentuan kualitas suatu makanan. Aroma yang khas dapat dirasakan oleh indra penciuman tergantung dari bahan penyusun dan bahan yang ditambahkan pada makanan tersebut. Aroma dalam bahan makanan dapat ditimbulkan oleh komponen- komponen volatil, akan tetapi komponen volatil tersebut dapat hilang selama proses pengolahan terutama panas (Fellows, 1990).

Atribut aroma yang dinilai oleh panelis pada uji mutu hedonik adalah aroma khas Enzyme Modified Cheese (EMC), EMC memiliki aroma khas dan menyengat (kuat) meskipun penambahannya sedikit. Aroma tersebut sangat disukai panelis karena saat diaplikasikan terhadap produk maka akan menghasilkan aroma yang disukai konsumen.

Skala mutu hedonik yang digunakan adalah semakin besar nilai maka semakin baik, dimana nilai 1 menunjukkan warna sangat tidak kuat dan nilai 6 menunjukan sangat kuat.

Berdasarkan hasil penelitian utama, uji mutu hedonik aroma terhadap Enzyme Modified Cheese (EMC) panelis rata- rata memberikan skala berkisar antara 1,94-2,25. Diketahui pada hasil perhitungan analisis variansi (ANAVA) menunjukkan bahwa perlakuan kecepatan pengadukan dan suhu fermentasi serta interaksi keduanya berpengaruh nyata. Pengaruh perbandingan kecepatan pengadukan dan suhu fermentasi kemudian dilakukan uji lanjut Duncan dengan hasil dapat dilihat pada Tabel 7, Tabel 8 dan Tabel 9. merupakan salah satu faktor yang berpengaruh terhadap proses pemecahan substrat, semakin tinggi kecepatan pengadukan maka maka aroma Enzyme Modified Cheese (EMC) semakin kuat dikarenakan enzim dibantu dengan agitasi dapat mempercepat pemutusan ikatan pada substrat menjadi senyawa volatil.

Tabel 7. Pengaruh Perlakuan Kecepatan Pengadukan Terhadap Aroma Enzyme Modified Cheese (EMC)

\begin{tabular}{|c|c|c|}
\hline $\begin{array}{c}\text { Kecepatan } \\
\text { Pengadukan }\end{array}$ & Nilai Rata-Rata & Taraf Nyata \\
\hline k1 (50 Rpm) & 2,06 & $\mathrm{a}$ \\
\hline $\mathrm{k} 2(60 \mathrm{Rpm})$ & 2,15 & $\mathrm{~b}$ \\
\hline $\mathrm{k} 3(70 \mathrm{Rpm})$ & 2,22 & $\mathrm{c}$ \\
\hline
\end{tabular}

Keterangan : semakin tinggi kecepatan pengadukan maka aroma produk akan meningkat.

Tabel 8. Pengaruh Perlakuan Suhu Fermentasi Terhadap Aroma Enzyme Modified Cheese (EMC)

\begin{tabular}{|c|c|c|}
\hline $\begin{array}{c}\text { Suhu } \\
\text { Fermentasi }\end{array}$ & Nilai Rata-Rata & Taraf Nyata \\
\hline $\mathrm{s} 2\left(45^{\circ} \mathrm{C}\right)$ & 2,09 & $\mathrm{a}$ \\
\hline $\mathrm{s} 1\left(40^{\circ} \mathrm{C}\right)$ & 2,12 & $\mathrm{a}$ \\
\hline $\mathrm{s} 3\left(50^{\circ} \mathrm{C}\right)$ & 2,22 & $\mathrm{~b}$ \\
\hline
\end{tabular}

Keterangan : semakin tinggi suhu fermentasi maka aroma produk akan meningkat.

Suhu fermentasi merupakan faktor yang berpengaruh terhadap munculnya aroma Enzyme Modified Cheese (EMC), dimana semakin tinggi suhu fermentasi mempercepat ikatan substrat terputus menjadi senyawa sederhana dan sebagian menjadi senyawa volatil.

Tabel 9. Pengaruh Interaksi kecepatan pengadukan dan suhu fermentasi Terhadap Aroma Enzyme Modified Cheese (EMC)

\begin{tabular}{|c|c|c|c|}
\hline \multirow{2}{*}{$\begin{array}{c}\text { Kecepatan } \\
\text { Pengadukan }\end{array}$} & \multicolumn{3}{|c|}{ Suhu Fermentasi } \\
\hline & $\begin{array}{c}\mathrm{S} 1 \\
\left(40^{0} \mathrm{C}\right)\end{array}$ & $\begin{array}{c}\mathrm{S} 2 \\
\left(45^{0} \mathrm{C}\right)\end{array}$ & $\begin{array}{c}\mathrm{S} 3 \\
\left(50^{0} \mathrm{C}\right)\end{array}$ \\
\hline k1 (50 & $\mathrm{A}$ & $\mathrm{A}$ & $\mathrm{C}$ \\
\hline Rpm) & 1,97 & 1,94 & 2,26 \\
\hline $\begin{array}{l}\text { k2 (60 } \\
\text { Rpm) }\end{array}$ & $\begin{array}{r}\mathrm{C} \\
2,20\end{array}$ & $\begin{array}{r}\mathrm{B} \\
2,12\end{array}$ & $\begin{array}{r}\mathrm{A} \\
2,13\end{array}$ \\
\hline $\begin{array}{l}\text { k3 (70 } \\
\text { Rpm) }\end{array}$ & $\begin{array}{r}\mathrm{BC} \\
2,18\end{array}$ & $\begin{array}{r}\mathrm{C} \\
\mathrm{b} \\
\mathrm{b}\end{array}$ & $\begin{array}{r}\mathrm{B} \\
2,25\end{array}$ \\
\hline
\end{tabular}

Keterangan : Huruf besar dibaca vertikal, huruf kecil dibaca horizontal. Setiap huruf yang sama tidak menunjukan perbedaan kecepatan pengadukan dan suhu 
fermentasi. Semakin tinggi nilai terhadap aroma maka produk semakin baik.

Berdasarkan tabel interaksi kecepatan pengadukan dan suhu fermentasi di didapat semakin tinggi kecepatan pengadukan dan suhu fermentasi maka aroma yang akan muncul semakin kuat disebabkan cepatnya ikatan pada substrat terputus sehingga nilai rata-rata terbesar ada pada kecepatan $70 \mathrm{Rpm}$ dan suhu 500C.

\section{Rasa}

Rasa merupakan faktor yang cukup penting dari suatu produk makanan. Komponen yang dapat menimbulkan rasa yang diinginkan tergantung dari senyawa penyusunnya. Rasa dinilai dengan adanya tanggapan rangsangan kimiawi oleh indera pencicip (lidah), dimana akhirnya keseluruhan interaksi antara sifat-sifat aroma, rasa, dan tekstur merupakan keseluruhan rasa makanan yang dinilai (Winarno, 1997).

Rasa yang diharapkan pada produk Enzyme Modified Cheese (EMC) adalah asin, asam, pahit. Rasa asin dan asam berasal dari keju cheddar sebagai bahan baku, juga karena adanya penambahan garam, rasa pahit berasal dari pemecahan protein oleh enzim, protein mengeluarkan aroma dan rasa pahit dari pemecahan rantai protein menjadi $\mathrm{NH} 3$, semakin tinggi kecepatan pengadukan dan semakin panas suhu fermentasi maka protein akan semakin banyak terpecah, begitupun dengan lemak. dan apabila tidak dikendalikan 2 faktor tersebut maka aroma khas EMC akan menurun atau tidak sesuai yang diinginkan.

Berdasarkan hasil data statistik dengan menggunakan anava yang dapat dilihat pada Tabel 10, Tabel 11 dan Tabel 12, menunjukan bahwa perlakuan perlakuan kecepatan pengadukan, suhu fermentasi serta interaksi antara keduanya berpengaruh nyata terhadap rasa. Hal ini dikarenakan rasa yang berlebihan dapat berpengaruh aplikasi terhadap produk. Sehingga dilakukan uji lanjut duncan.

Tabel 10. Pengaruh Perlakuan Kecepatan Pengadukan Terhadap Rasa Enzyme Modified Cheese (EMC)

\begin{tabular}{|c|c|c|}
\hline $\begin{array}{c}\text { Kecepatan } \\
\text { Pengadukan }\end{array}$ & Nilai Rata-Rata & Taraf Nyata \\
\hline k1 (50 Rpm) & 2,14 & $\mathrm{a}$ \\
\hline k2 (60 Rpm) & 2,25 & $\mathrm{~b}$ \\
\hline k3 (70 Rpm) & 2,32 & $\mathrm{c}$ \\
\hline
\end{tabular}

Keterangan : semakin tinggi kecepatan pengadukan maka intensitas rasa kuat pada produk akan meningkat.

Kecepatan pengadukan berpengaruh terhadap rasa dalam pembuatan Enzyme Modified Cheese (EMC) dikarenakan faktor ini mempercepat proses pemutusan rantai pada substrat, semakin tinggi kecepatan pengadukan maka akan meningkatkan suhu fermentasi dan akan menguraikan subtrat menjadi senyawa yang lebih sederhana, namun apabila tidak dikendalikan protein dan lemak akan terpecah menjadi rasa yang tidak diinginkan yaitu pahit dan tengik.

Suhu fermentasi berpengaruh dalam proses pembuatan EMC, dimana enzim bekerja pada suhu optimal 500C, dalam proses menonaktifkan enzim suhu dinaikkan sampai 900C selama 5 menit, dalam proses ini enzim mati dan tidak bekerja, namun substrat yang telah terurai akan mengeluarkan rasa khasnya masingmasing.

Interaksi kedua faktor ini memberikan rasa yang khas, semakin tinggi kecepatan pengadukan dan suhu fermentasi maka rasa khas EMC semakin kuat, hal ini dikarenakan substrat telah terurai dan mengeluarkan rasa khasnya masing-masing. Rasa EMC yang diinginkan yaitu asin, sedikit pahit, sedikit asam, dan masih terasa rasa keju yang cukup kuat.

Tabel 11. Pengaruh Perlakuan Suhu Fermentasi Terhadap Rasa Enzyme Modified Cheese (EMC)

\begin{tabular}{|c|c|c|}
\hline $\begin{array}{c}\text { Suhu } \\
\text { Fermentasi }\end{array}$ & Nilai Rata-Rata & Taraf Nyata \\
\hline $\mathrm{s} 1\left(40^{\circ} \mathrm{C}\right)$ & 2,19 & $\mathrm{a}$ \\
\hline $\mathrm{s} 2\left(45^{\circ} \mathrm{C}\right)$ & 2,21 & $\mathrm{a}$ \\
\hline $\mathrm{s} 3\left(50^{\circ} \mathrm{C}\right)$ & 2,30 & $\mathrm{~b}$ \\
\hline
\end{tabular}

Keterangan : semakin tinggi suhu fermentasi maka intensitas rasa yang kuat pada produk akan meningkat.

Tabel 12. Pengaruh Interaksi Faktor Kecepatan Pengadukan dan Suhu Fermentasi Terhadap Rasa

\begin{tabular}{|c|c|c|c|}
\hline \multirow{2}{*}{$\begin{array}{l}\text { Kecepatan } \\
\text { Pengaduk an }\end{array}$} & \multicolumn{2}{|c|}{ Suhu Fermentasi } & \\
\hline & $\begin{array}{c}\mathrm{S} 1 \\
\left(40^{0} \mathrm{C}\right)\end{array}$ & $\begin{array}{c}\mathrm{S} 2 \\
\left(45^{0} \mathrm{C}\right)\end{array}$ & $\begin{array}{c}\mathrm{S} 3 \\
\left(50^{0} \mathrm{C}\right)\end{array}$ \\
\hline k1 (50 & $\mathrm{A}$ & $\mathrm{A}$ & $\mathrm{B}$ \\
\hline $\mathrm{Rpm})$ & $\begin{array}{r}2,08 \\
a^{2}\end{array}$ & 2,03 & 2,29 \\
\hline $\begin{array}{l}\text { k2 (60 } \\
\text { Rpm) }\end{array}$ & 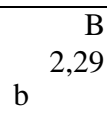 & $\begin{array}{r}\mathrm{A} \\
2,18\end{array}$ & $\begin{array}{r}\mathrm{A} \\
2,25\end{array}$ \\
\hline $\begin{array}{l}\text { k3 (70 } \\
\text { Rpm) }\end{array}$ & $\begin{array}{r}\mathrm{A} \\
\quad 2,28 \\
\mathrm{a}\end{array}$ & $\begin{array}{r}\mathrm{B} \\
2,32\end{array}$ & $\begin{array}{r}\mathrm{A} \\
2,32\end{array}$ \\
\hline
\end{tabular}

Keterangan : Huruf besar dibaca vertikal, huruf kecil dibaca horizontal. Setiap huruf yang sama tidak menunjukan perbedaan nyata. Semakin tinggi kecepatan pengadukan dan suhu fermentasi, maka semakin tinggi nilai terhadap rasa EMC.

Berdasarkan tabel interaksi didapat hasil nilai rata-rata tertinggi yaitu pada kecepatan $70 \mathrm{Rpm}$ dan suhu 500C dengan nilai 2,37. Ini menunjukan bahwa rasa EMC ada pada skala tidak kuat. Beberapa faktor yang menyebabkan rasa EMC tidak kuat diantaranya belum dilakukannya aging.

Berdasarkan penelitian yang telah dilakukan, maka dapat disimpulkan sebagai berikut :

1. Berdasarkan hasil penelitian pendahuluan, sampel yang dipilih untuk dilanjutkan pada penelitian utama adalah sampel dengan lama fermentasi 10 jam dengan hasil organoleptik aroma 2,30, rasa 2,39, 
kadar air 52,69\%, kadar protein 8,14 dan kadar lemak $23,87 \%$.

2. Faktor kecepatan pengadukan berpengaruh nyata terhadap aroma, rasa, kadar air, dan kadar lemak Enzyme Modified Cheese (EMC).

3. Faktor variasi suhu fermentasi berpengaruh nyata terhadap aroma, rasa, kadar air, dan kadar lemak Enzyme Modified Cheese (EMC).

4. Interaksi antara faktor perbandingan variasi kecepatan pengadukan fermentor dan variasi suhu fermentasi berpengaruh nyata terhadap aroma dan rasa, kadar air dan kadar protein Enzyme Modified Cheese (EMC).

\section{Daftar Pustaka}

1. AOAC. 2010. Official Methode of Analysis of The Association Analitical Chemist. Inc., Washington DC.

2. Biro Pusat Statistik, (2014). Statistik Peternakan. Jakarta: BPS.

3. Buckle, K. A., dkk.1987. Ilmu Pangan. UI Press. Jakarta.

4. M. Mohebbi, J. Barouei et al. 2008. Modeling and Optimization of Viscosity in Enzym Modified Cheese by Fuzzy Logic and Genetic Algoritm. Ferdowsi University, Iran. Patrick F., Fox, Timothy P. Guinee, Timothy M. Cogan, dan Paul L. H. McSweeney. 2000. Fundamentals Of Cheese Science. United States of America.

5. Setyawati, A., Purwadi, dan I. Thohari. 2013. Kualitas fisik dan organoleptik (Aroma, Warna) keju olahan dengan penambahan tepung porang (Amorphopallus onchophillus). Fakultas Peternakan Universitas Brawijaya, Malang.

6. Soekarto, T. S. (1986). Penilaian Organoleptik. Jakarta : Bharata Karya Aksara.

7. Winarno, F.G., 1993. Pangan Gizi Teknologi dan Konsumen. Gramedia Pustaka Utama, Jakarta. 